\title{
CHEMICAI SENSORS
}

\section{XIMIYHI CEHCOPИ}

PACS 73.63.-b

УДК 537.312

\section{ГАЗОВІ СЕНСОРИ НА ОСНОВІ ОРГАНО-НЕОРГАНІЧНИХ НАНОКОМПОЗИТІВ}

\author{
І. Б. Оленич, Л. С. Монастирський, О. І. Аксіментьєва, Ю. Ю. Горбенко \\ Львівський національний університет імені Івана Франка, \\ вул. Драгоманова, 50, 79005 м. Львів, Україна, \\ Тел. (032)239-46-23, e-mail: iolenych@gmail.com
}

\section{ГАЗОВІ СЕНСОРИ НА ОСНОВІ ОРГАНО-НЕОРГАНІЧНИХ НАНОКОМПОЗИТІВ}

\section{І. Б. Оленич, Л. С. Монастирський, О. І. Аксіментьєва, Ю. Ю. Горбенко}

Анотація. Створено сенсорні елементи на основі композитних плівок полі-3,4етилендиоксітіофену у поєднанні з нанокристалами поруватого кремнію та оксиду цинку. Зареєстровано збільшення електричного опору нанокомпозиту внаслідок адсорбції молекул аміаку, етанолу та ацетону. Для оцінки сенсорних властивостей розраховано адсорбційну чутливість одержаних композитних плівок і досліджені їх динамічні характеристики. Встановлено, що максимальна чутливість сенсорних елементів знаходиться в діапазоні концентрацій аналізованих газів 1-2 \%, а час відклику становить 60-80 с. Керувати функціональними параметрами плівкових сенсорів можна змінюючи співвідношення між вмістом напівпровідникових наночастинок у гібридному композиті.

Ключові слова: сенсори, адсорбційна чутливість, нанокомпозит, поруватий кремній, оксид цинку, полі-3,4-етилендиоксітіофен

\section{GAS SENSORS BASED ON THE ORGANIC-INORGANIC NANOCOMPOSITES}

\section{B. Olenych, L. S. Monastyrskii, O. I. Aksimentyeva, Yu. Yu. Horbenko}

Abstract. Sensor elements based on composite films of poly-3,4-ethylenedioxythiophene combined with nanocrystals of porous silicon and zinc oxide were created. Increasing of nanocomposite electrical resistance due to adsorption of ammonia, ethanol and acetone molecules was registered. To evaluate the

(C) І. Б. Оленич, Л. С. Монастирський, О. І. Аксіментьєва, Ю. Ю. Горбенко, 2016 
sensor properties, adsorption sensitivity of obtained composite films was calculated and their dynamic characteristics were studied. It was established that the maximum sensitivity of the sensor elements ranges between concentrations $1-2 \%$ of the analyzed gases and response time is $60-80 \mathrm{~s}$. To control functional parameters of the sensor films, the content ratio of semiconductor nanoparticles in hybrid composite can be changed.

Keywords: sensors, adsorption sensitivity, nanocomposite, porous silicon, zinc oxide, poly $(3,4-$ ethylenedioxythiophene)

\title{
ГАЗОВЫЕ СЕНСОРЫ НА ОСНОВЕ ОРГАНО-НЕОРГАНИЧЕСКИХ НАНОКОМПОЗИТОВ
}

\section{И. Б. Оленич, Л. С. Монастырский, Е. И. Аксиментьева, Ю. Ю. Горбенко}

\begin{abstract}
Аннотация. Созданы сенсорные элементы на основе композиционных пленок поли-3,4етилендиокситиофена в сочетании с нанокристаллами пористого кремния и оксида цинка. Зарегистрировано увеличение сопротивления нанокомпозита в результате адсорбции молекул аммиака, этанола и ацетона. Для оценки сенсорных свойств была рассчитана адсорбционная чувствительность полученных композитных пленок и исследованы их динамические характеристики. Установлено, что максимальная чувствительность сенсорных элементов находится в диапазоне концентраций анализируемых газов 1-2\%, а время отклика составляет 60-80 с. Управлять функциональными параметрами пленочных сенсоров можно изменяя соотношение между содержанием полупроводниковых наночастиц в гибридном композите.

Ключевые слова: сенсоры, адсорбционная чувствительность, нанокомпозит, пористый кремний, оксид цинка, поли-3,4-етилендиокситиофен
\end{abstract}

\section{Вступ}

Швидкий розвиток наноелектроніки пов'язаний $з$ пошуком нових функціональних матеріалів $з$ прогнозованими властивостями. Сьогодні приділяється значна увага вивченню властивостей композитних середовищ, які поєднують в собі властивості полімерів і неорганічних наночастинок різної природи. Перспективною основою органо-неорганічних композитів $є$ електропровідні полімери, характерною рисою яких є наявність спряженої системи $\pi$-електронних зв'язків $[1,2]$. Перекривання електронних рівнів зумовлює утворення єдиної делокалізованої системи, яка визначає електропровідні властивості спряжених полімерів. Особливу увагу привертає полі-3,4-етилендиоксітіофен (ПЕДОТ) завдяки досить високій електропровідності та цікавим електрохімічним властивостям [3-5]. За допомогою легування електропровідність ПЕДОТ може змінюватися від в широких межах - від 0,1 до $10^{8}$ Ом•см. Ці зміни відбуваються під дією допування - дедопування спряженого полімерного ланцюга частинками донорного або акцепторного типу, зокрема, молекулами газів, що розширює перспективу застосування полімеру в сенсорній електроніці [6-8].

Інкорпорація в електропровідні полімери напівпровідникових компонентів, таких як наночастинки поруватого кремнію (ПК) та оксиду цинку $(\mathrm{ZnO})$, дає змогу максимально використати окисно-відновну активність спряжених полімерів, розмірні ефекти і значну площу поверхні напівпровідникових наноструктур $[9,10]$. Наноструктури ПК і ZnO з розвинутою поверхнею виявляють суттєву залежність електричних і люмінесцентних властивостей від адсорбції молекул різних газів чи парів органічних речовин та викликають значний інтерес як чутливі елементи хімічних і біологічних сенсорних пристроїв [11-14].

Можна очікувати, що використання композитів на основі ПЕДОТ у поєднанні з напівпровідниковими нанокристалами може сприяти 
підвищенню чутливості до хімічних сполук, селективності та швидкодії плівкових сенсорів, виготовлених за відносно простою і недорогою технологією [15]. Тому мета цієї роботи полягала у створенні сенсорних елементів на основі композитних плівок ПЕДОТ-ПК-ZnO і вивченні впливу адсорбції молекул аміаку $\left(\mathrm{NH}_{3}\right)$, етанолу $\left(\mathrm{C}_{2} \mathrm{H}_{5} \mathrm{OH}\right)$ та ацетону $\left(\left(\mathrm{CH}_{3}\right)_{2} \mathrm{CO}\right)$ на їх електричні параметри.

\section{Експеримент}

Для виготовлення плівки гібридного композиту ПЕДОТ-por-Si-ZnO використовувались полі-3,4-етилендиоксітіофен у вигляді водної суспензії із вмістом основної речовини $1 \%$, стабілізованої аніонною поверхнево активною речовиною - полістиренсульфоновою кислотою, яка одночасно діє як кислотна легуюча домішка [3], частинки $\mathrm{ZnO}$ розміром до $100 \mathrm{Hм}$ виробництва фірми Sigma-Aldrich Со (США) i нанокристали ПК.

Шари ПК були отримані методом електрохімічного травлення кремнієвих пластин товщиною 400 мкм кристалографічної орієнтації (100), електронного типу провідності 3 питомим опором 4,5 Ом·см в етанольному розчині фтористоводневої кислоти у співвідношенні $\mathrm{HF}: \mathrm{C}_{2} \mathrm{H}_{5} \mathrm{OH}=1: 1$. Густина анодного струму була постійною в часі і становила $30 \mathrm{MA} / \mathrm{cm}^{2}$, а тривалість процесу анодування 10-20 хв. Для забезпечення наявності в приповерхневому шарі n-Si носіїв заряду позитивного знаку, необхідних для перебігу анодних реакцій і формування ПК [16], робоча поверхня кремнієвої пластини опромінювалась вольфрамовою лампою потужністю 500 Вт упродовж всього процесу електрохімічного травлення. Після промивання зразків дистильованою водою та висушування на повітрі з поверхні пластини механічним методом знімався поруватий шар у вигляді дрібнодисперсного порошку. Одержаний порошок ПК змішувався з наночастинками $\mathrm{ZnO}$ у різному об'ємному співвідношенні (2:1 та 1:2).

Гібридний композит ПЕДОТ-ПК-ZnO був отриманий шляхом змішування 0,25 мл суміші наночастинок ПК та $\mathrm{ZnO}$ з 0,75 мл розчину по- лімеру ПЕДОТ. Одержану суспензію піддавали ультразвуковій обробці, після чого наносили на скляну підкладку розміром $8 \times 8$ мм та висушували при кімнатній температурі впродовж 3-х діб для випаровування розчинника і формування монолітної плівки. У результаті на підкладці утворилась плівка нанокомпозиту ПЕДОТ-ПК-ZnO товщиною близько 20 мкм, на поверхню якої були осаджені термовакуумним методом срібні контакти, товщиною близько 0,5 мкм на відстані 4 мм один від одного.

Мікроструктура гібридної плівки ПЕДОТПК-ZnO була досліджена за допомогою скануючого електронного мікроскопу (CEM) Selmi РЕММА-102.

Дослідження адсорбційно-десорбційних процесів у плівкових сенсорних елементах на основі композиту ПЕДОТ-ПК-ZnO під дією молекул аміаку, етанолу та ацетону проводились у герметичній камері, газове середовище якої можна було змінювати. Контроль за газовим середовищем здійснювався за допомогою системи напуску газів СНА-2. Вимірювання електричних параметрів досліджуваних сенсорних елементів здійснювали за допомогою електрометра В7-30.

\section{Результати та їх обговорення}

Утворення суцільної плівки нанокомпозиту ПЕДОТ-ПК-ZnO підтверджується даними скануючої електронної мікроскопії. СЕМзображення поверхні гібридної плівки в режимі вторинних і пружно відбитих електронів приведені на Рис. 1. Дослідження виявили значний розкид дисперсності порошку ПК, змішаного $з$ наночастинками $\mathrm{ZnO}$. У режимі пружно відбитих електронів ділянки СЕМ-зображення з більшою яскравістю можна ідентифікувати як наноструктури ZnO (див. Рис.1,б). Суміш напівпровідникових наночастинок була інтегрована в полімерну плівку, рельєф якої зумовлював збільшення робочої поверхні сенсорного елемента i, відповідно, підвищення його чутливості. 


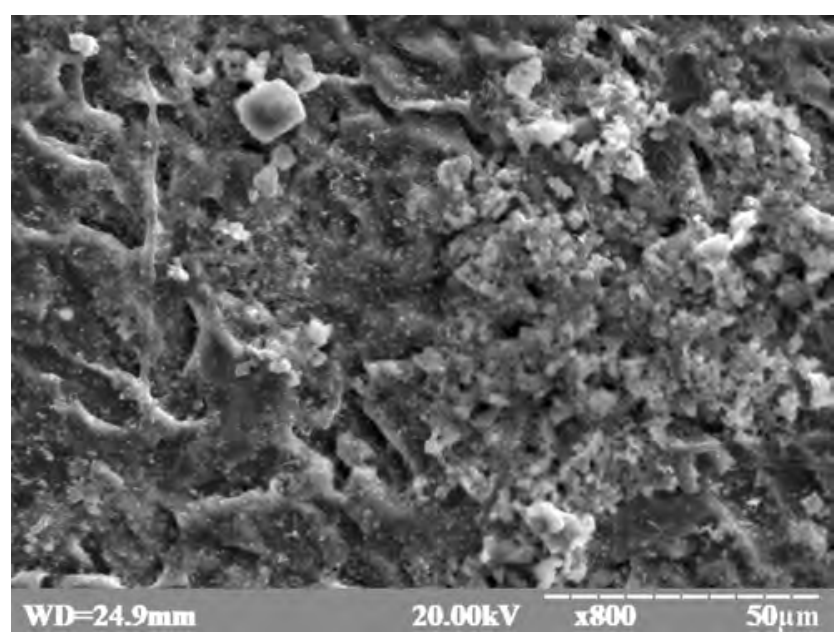

(a)

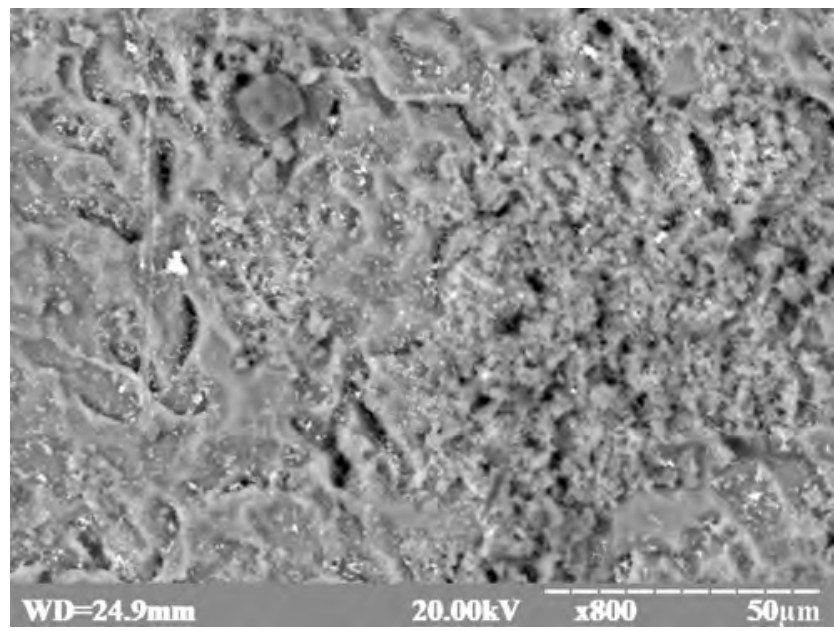

(б)

Рис. 1. СЕМ зображення поверхні плівки композиту ПЕДОТ-ПК-ZnO в режимі вторинних (a) та пружно відбитих (б) електронів.

Експериментальні дослідження виявили суттєву залежність електричних параметрів композитних плівок ПЕДОТ-ПК-ZnO від складу оточуючої атмосфери. У випадку збільшення концентрації молекул аміаку, етанолу чи ацетону в експериментальній камері спостерігалося монотонне зростання електричного опору сенсорного елемента на основі нанокомпозиту ПЕДОТ-ПК-ZnO, причому характер залежності був схожий для зразків із різним співвідношенням напівпровідникових компонентів (Рис. 2).

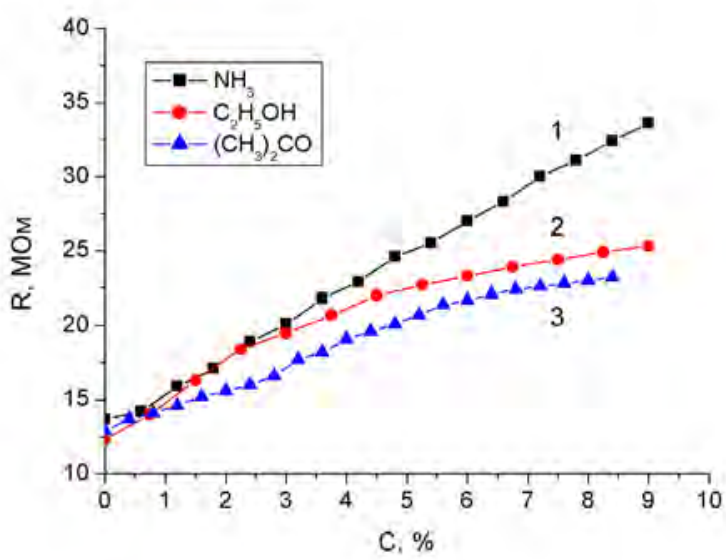

(a)

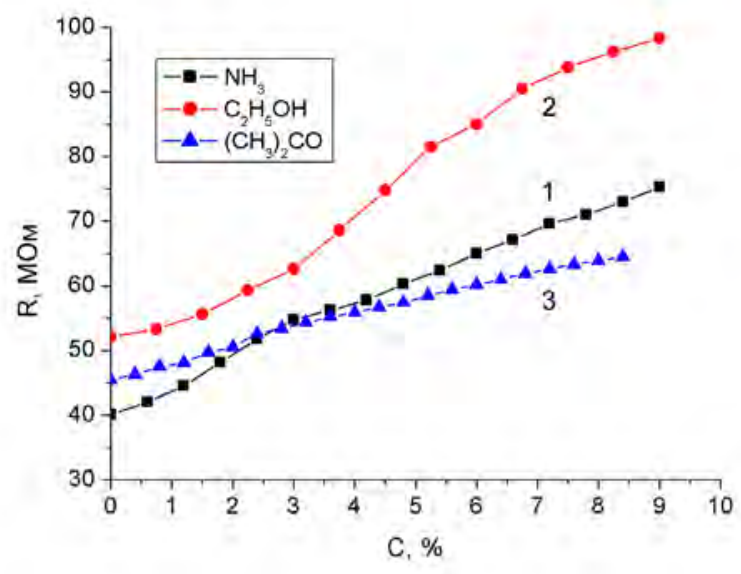

(б)

Рис. 2. Залежність електричного опору плівок ПЕДОТ-ПК-ZnO $з$ співвідношенням нанокристалів ПК:ZnO=2:1 (а) і ПК:ZnO=1:2 (б) від концентрації молекул аміаку (1), етанолу (2) i ацетону (3).

При низьких концентраціях молекул аміаку (до 10 \%) композитна плівка з об'ємним співвідношенням нанокристалів ПК: $\mathrm{ZnO}=2: 1$ володіла лінійною концентраційною залежністю електричного опору (див. Рис.2,a), що є вагомою перевагою при розробці газових сенсорів і свідчить про рівномірну чутливість сенсорного елемента до молекул $\mathrm{NH}_{3}$ у широкому діапазоні їх концентрації. У випадку адсорбції молекул $\mathrm{C}_{2} \mathrm{H}_{5} \mathrm{OH}$ та $\left(\mathrm{CH}_{3}\right)_{2} \mathrm{CO}$ спостерігалась сублінійна залежність опору плівки ПЕДОТ-ПК-ZnO від концентрації молекул досліджуваних органічних сполук. 
Композитна плівка з об'ємним співвідношенням нанокристалів ПК: $\mathrm{ZnO}=1: 2$ володіла майже лінійною залежністю опору від концентрації молекул ацетону, а також більшим діапазоном зміни електричного опору внаслідок адсорбції молекул етанолу (див. Рис.2,б).

Отримані залежності зумовлені взаємодією полярних молекул аналізованих газів 3 поверхнею композиту ПЕДОТ-ПК-ZnO, що призводить до зміни провідності полімеру та електронних параметрів напівпровідникових нанокристалів за рахунок адсорбо-електричних ефектів [12]. Окисно-відновні процеси в спряжених полімерах, зумовлені адсорбованими молекулами, відіграють роль додаткового легування, яке призводить до спостережуваного збільшення електричного опору композитної плівки ПЕДОТ-ПК-ZnO. Враховуючи високу чутливість ПК до аміаку [17,18] і наноструктур $\mathrm{ZnO}$ до етанолу і ацетону $[19,20]$, використання композитних матеріалів 3 такими напівпровідниковими наночастинками забезпечує не лише збільшення площі робочої поверхні сенсорних елементів, але й високу чутливість і селективність до аналізованих газів. Керувати функціональними параметрами плівкових сенсорів можна змінюючи співвідношення між вмістом нанокристалів ПК і ZnO у гібридному композиті. Слід зазначити, що збільшення вмісту оксиду цинку в композиті спричиняло зменшення електропровідності гібридної плівки, що може бути зумовлено більш високим опором наночастинок широкозонного $\mathrm{ZnO}$ у порівнянні $з$ опором наноструктур ПК.

Важливим фактором дослідження механізмів зміни фізичних параметрів сенсорних матеріалів при адсорбційно-десорбційних взаємодіях з газовим середовищем є визначення адсорбційної чутливості матеріалу. Для оцінки сенсорних властивостей плівки нанокомпозиту ПЕДОТ-ПК-ZnO було розраховано адсорбційну чутливість за співвідношенням [21]:

$$
\gamma_{R}=\frac{1}{R} \frac{\Delta R}{\Delta C},
$$

де $\Delta R / R$ - відносна зміна електричного опору, $\Delta C$ - зміна концентрації молекул аналізованих газів. Розраховані залежності чутливості сенсорних елементів на основі нанокомпозиту ПЕДОТ-ПК-ZnO з різним вмістом напівпро- відникових компонентів від концентрації аналізованих газів показані на Рис. 3.

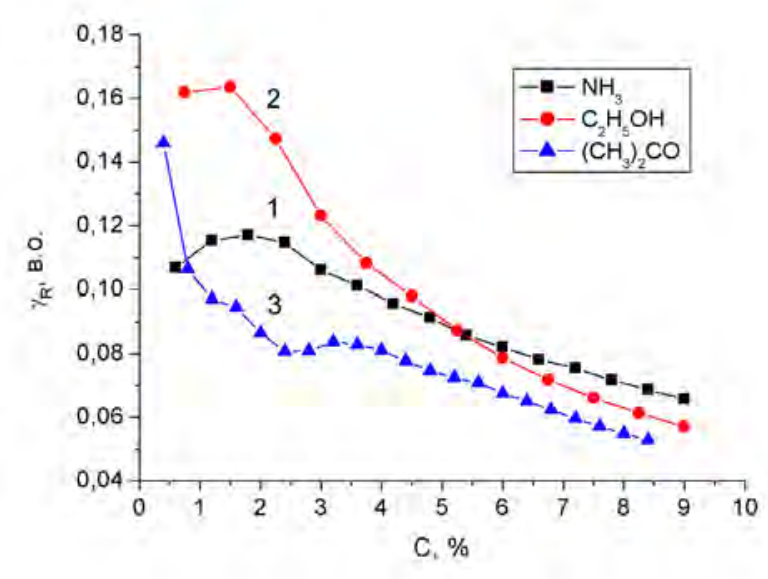

(a)

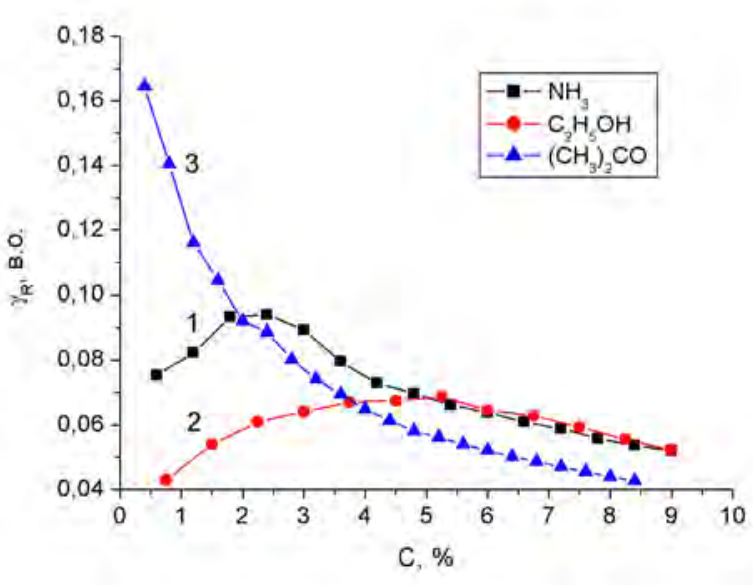

(б)

Рис. 3. Залежність адсорбційної чутливості сенсорних елементів на основі плівок ПЕДОТПК-ZnO з співвідношенням нанокристалів ПК:ZnO=2:1 (a) і ПК:ZnO=1:2 (б) від концентрації молекул аміаку (1), етанолу (2) і ацетону (3).

На основі розрахованих концентраційних залежностей чутливості встановлено, що сенсорні елементи володіють більшою адсорбційною чутливістю в області малих концентрацій аналізованих газів. Композитні плівки з більшим вмістом нанокристалів ПК виявили більшу чутливість до адсорбції молекул $\mathrm{C}_{2} \mathrm{H}_{5} \mathrm{OH}$ та $\mathrm{NH}_{3}$. У випадку співвідношення компонентів плівки ПК: $\mathrm{ZnO}=1: 2$ спостерігалися більші значення чутливості до молекул $\left(\mathrm{CH}_{3}\right)_{2} \mathrm{CO}$ при ïх концентрації близько 1 \% і максимум адсорбційної чутливості до молекул $\mathrm{C}_{2} \mathrm{H}_{5} \mathrm{OH}$ при концентрації близько 5 \%. 

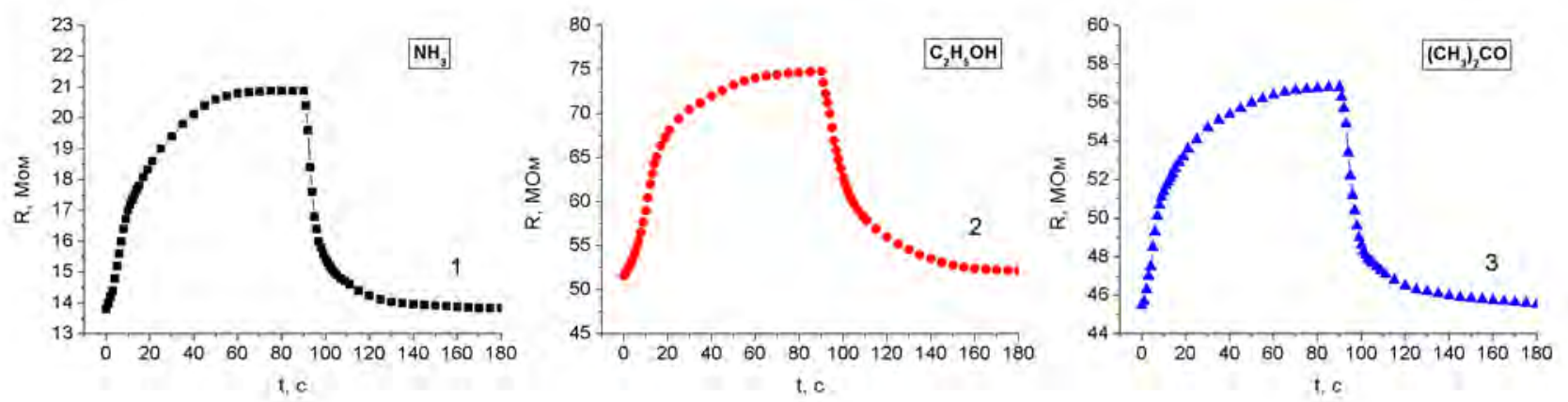

Рис. 4. Відклик електричного опору плівок ПЕДОТ-ПК-ZnO на зміну концентрації молекул аміаку (1), етанолу (2) і ацетону (3).

Динамічні залежності відклику плівкових сенсорних елементів на основі нанокомпозиту ПЕДОТ-ПК-ZnO показані на Рис.4. Спостерігалось майже повне відновлення початкових значень електричного опору плівкових сенсорних елементів після продувки та відкачування з камери молекул аміаку, етанолу чи ацетону у випадку, коли їх концентрація не перевищувала 10 \%. Це може свідчити про фізичний характер адсорбції аналізованих молекул поверхнею композитної плівки.

Час відповіді сенсорних елементів на різке зростання концентрації молекул $\mathrm{NH}_{3}, \mathrm{C}_{2} \mathrm{H}_{5} \mathrm{OH}$ та $\left(\mathrm{CH}_{3}\right)_{2} \mathrm{CO}$ і час відновлення складають близько 60 та 80 с відповідно, причому дещо швидше працюють сенсори аміаку. У порівнянні з сенсорними структурами ПК - кремнієва підкладка [22] час відклику гібридних плівкових сенсорів був у 2-3 рази менший. В цілому, час відклику є достатньо малим для мікроелектронних газових сенсорів.

\section{Висновки}

За допомогою нескладної технології створено плівкові сенсорні елементи на основі гібридного композиту ПЕДОТ-ПК-ZnO. Поєднання наночастинок поруватого кремнію та оксиду цинку забезпечує не лише збільшення площі робочої поверхні сенсорів, але й високу чутливість і селективність до молекул аміаку, етанолу та ацетону.

Експериментально встановлено, що адсорбція молекул аналізованих газів збільшує електричний опір плівок ПЕДОТ-ПК-ZnO, причому залежність опору від концентрації молекул аміаку та ацетону була майже лінійною. На основі експериментальних даних розраховано залежність адсорбційної чутливості сенсорних елементів від концентрації аналізованих газів і встановлено, що максимум чутливості композитних плівок ПЕДОТ-ПК- $\mathrm{ZnO}$ знаходиться в області концентрацій близько 1-2\%. Крім того, адсорбційна чутливість залежить від складу нанокомпозиту: плівки з більшим вмістом ПК володіють більшою чутливістю до адсорбції молекул $\mathrm{C}_{2} \mathrm{H}_{5} \mathrm{OH}$ та $\mathrm{NH}_{3}$, а плівки з більшим вмістом наночастинок $\mathrm{ZnO}$ - до адсорбції молекул $\left(\mathrm{CH}_{3}\right)_{2} \mathrm{CO}$.

Кінетика відклику сенсорних елементів на основі композитних плівок ПЕДОТ-ПК-ZnO на зміну концентрації молекул аналізованих газів є достатньо швидкою для мікроелектронних сенсорів вологості та становить близько 60-80 с. Таким чином, одержані результати можна використати для створення ефективних газоаналізаторів.

\section{Список використаної літератури}

1. A. J. Heeger. Semiconducting and metallic polymers: the fourth generation of polymeric materials // Synth. Metals, 123, pp. 23-42 (2002).

2. R. S. Kohlman, J. Joo, A. J. Epstein. Conducting polymers: electrical conductivity. Physical properties of polymers handbook. J. E. Mark ed. Amer. Inst. Phys. Woodbury, New-York. 453-478 (1996).

3. J. Ouyang, Q. Xu, C. -W. Chu, Y. Yang, G. Li, J. Shinar. On the mechanism of conductivity enhancement in poly $(3,4-$ ethylenedioxythiophene): poly(styrene 
sulfonate) film through solvent treatment // Polymer, 45(25), pp. 8443-8450 (2004).

4. O. Pyshkina, A. Kubarkov, V. Sergeyev. Poly(3,4-ethylenedioxythiophene): synthesis and properties // Mater. Sci. App. Chem., 21, pp. 51-54 (2010).

5. L. S. Monastyrskii, O. I. Aksimentyeva, I. B. Olenych, B. S. Sokolovskii. Photosensitive structures of conjugated polymer - porous silicon // Mol. Cryst. Liq. Cryst., 589, pp. 124-131 (2014).

6. Ph. Leclere, M. Surin, P. Brocorens, M. Cavallini, F. Biscarini, R. Lazzaroni. Supramolecular assembly of conjugated polymers: From molecular engineering to solid-state properties // Mater. Sci. Engin. R, 55, pp. 1-56 (2006).

7. H. Bai, G. Shi. Gas sensors based on conducting polymers // Sensors, 7, pp. 267-307 (2007).

8. M. Kuş, S. Okur. Electrical characterization of PEDOT:PSS beyond humidity saturation // Sensor Actuator B, 143, pp. 177-181 (2009).

9. O. Bisi, S. Ossicini, L. Pavesi. Porous silicon: a quantum sponge structure for silicon based optoelectronics // Surf. Sci. Rep., 38, pp. 1-126 (2000).

10. Z. L. Wang. Zinc oxide nanostructures: growth, properties and applications // Journal of Physics: Condensed Matter, 16, pp. R829-R858 (2004).

11. S. Ozdemir, J. Gole. The potential of porous silicon gas sensors // Curr. Opin. in Solid State and Mater. Science., 11, pp. 92-100 (2007).

12. L. S. Monastyrskii, I. B. Olenych, O. I. Aksimentyeva, B. S. Sokolovskii, M. R. Pavlyk. Gas adsorption sensors on the basis of porous silicon // Sensor Electronics and Microsystems Technologies, 8(3), pp. 38-43 (2011) (in Ukrainian).

13. R. Kumar, O. Al-Dossary, G. Kumar, A. Umar. Zinc Oxide Nanostructures for $\mathrm{NO}_{2}$ Gas-Sensor Applications: A Review // Nano-Micro Lett., (2014). DOI: 10. 1007/s40820-014-0023-3.
14. I. C. Yao, P. Lin, T. Y. Tseng. Hydrogen gas sensors using $\mathrm{ZnO}-\mathrm{SnO}_{2}$ core-shell nanostructure // Advanced Science Letters, 3, pp. 548-553 (2010).

15. I. B. Olenych, O. I. Aksimentyeva, L. S. Monastyrskii, Y. Y. Horbenko, L. I. Yarytska. Sensory properties of hybrid composites based on poly (3,4ethylenedioxythiophene)-porous silicon-carbon nanotubes // Nanoscale Res. Lett., 10, pp. 187-1-187-6. (2015).

16. A. G. Cullis, L. T. Canham, P. D. J. Calcott. The structural and luminescence properties of porous silicon // J. Appl. Phys., 82, pp. 909-965 (1997).

17. Yu. A. Vashpanov, Electronic properties and adsorption sensitivity to ammonia of microporous silicon // Ukr. J. Phys., 44 (4), pp. 468-470 (1999) (in Ukrainian).

18. S. Ozdemir, J. Gole. Porous silicon gas sensors for room temperature detection of ammonia and phosphine // ECS Transactions, 16 (11), pp. 379-385 (2008).

19. J. J. Delaunay, N. Kakoiyama, I. Yamada. Fabrication of three-dimensional network of $\mathrm{ZnO}$ tetratpods and its response to ethanol // Materials Chemistry and Physics, 104, pp. 141-145 (2007).

20. S. S. Karpova, V. A. Moshnikov, S. V. Mjakin, E. S. Kolovangina. Surface functional composition and sensor properties of $\mathrm{ZnO}, \mathrm{Fe}_{2} \mathrm{O}_{3}$, and $\mathrm{ZnFe}_{2} \mathrm{O}_{4}$ // Semiconductors, 47, pp. 392-395 (2013).

21. Yu. A. Vashpanov and V. A. Smyntyna, Adsorption Sensitivity of Semiconductors. Astroprint, Odesa. 216 (2005) (in Russian).

22. I. B. Olenych, L. S. Monastyrskii, O. I. Aksimentyeva, B. S. Sokolovskii. Humidity sensitive structures on the basis of porous silicon // Ukr. J. Phys., 56(11), pp. 1198-1202 (2011).

Стаття надійшла до редакції 17.03.2016 р. 
PACS 73.63.-b UDC 537.312

\title{
GAS SENSORS BASED ON ORGANIC-INORGANIC NANOCOMPOSITES
}

\author{
I. B. Olenych, L. S. Monastyrskii, O. I. Aksimentyeva, Yu. Yu. Horbenko \\ Ivan Franko National University of Lviv, \\ 50 Drahomanova Str., 79005 Lviv, Ukraine
}

\begin{abstract}
Summary
The use of nanocrystals with large specific surface in sensor structures provides their high sensitivity to molecules of adsorbed gases. The aim of the work was to create sensor elements based on composite films of poly-3,4-ethylenedioxythiophene (PEDOT) in combination with nanocrystals of porous silicon (PS) and zinc oxide ( $\mathrm{ZnO}$ ) and to study the effect of adsorption of ammonia, ethanol and acetone molecules on the electrical parameters of the PEDOT-PS-ZnO structure.

To produce film of PEDOT-PS-ZnO hybrid composite, $1 \%$ suspension of PEDO-PSS, zinc oxide with a particle size of $100 \mathrm{~nm}$ (Sigma-Aldrich Co, USA) and PS nanocrystals, obtained by electrochemical etching of silicon wafer were used. Research of adsorption-desorption processes in the composite films was carried out by measuring their electrical parameters at different concentrations of the analyzed gases. To evaluate the sensor properties, the adsorption sensitivity of the composite films was calculated and their dynamic characteristics were studied.

Increase of electrical resistance of nanocomposite due to adsorption of ammonia, ethanol and acetone molecules was registered. The almost linear dependence of the resistance on the concentration of ammonia and acetone was observed. It is a significant advantage in developing of the gas sensors. The maximum sensitivity of the sensor elements is in the range of $1-2 \%$ concentration of the analyzed gases and the response time is 60-80 s. The films with higher content of PS nanocrystals were more sensitive to molecules of ammonia and ethanol, and the films containing more nanoparticles of $\mathrm{ZnO}$ - to molecules of acetone. To control functional parameters of the sensor films, the content ratio of semiconductor nanoparticles in hybrid composite can be changed.

The combination of nanoparticles of porous silicon and zinc oxide provides not only an increase in working surface area of sensors, but also high sensitivity and selectivity to the ammonia, ethanol and acetone molecules. The obtained results can be used to create effective analyzers of gases.

Keywords: sensors, adsorption sensitivity, nanocomposites, porous silicon, zinc oxide, poly-3,4ethylenedioxythiophene
\end{abstract}


PACS 73.63.-b УДК 537.312

\title{
ГАЗОВІ СЕНСОРИ НА ОСНОВІ ОРГАНО-НЕОРГАНІЧНИХ НАНОКОМПОЗИТІВ
}

\author{
І. Б. Оленич, Л. С. Монастирський, О. І. Аксіментьєва, Ю. Ю. Горбенко \\ Львівський національний університет імені Івана Франка, \\ вул. Драгоманова, 50, 79005 м. Львів, Україна,
}

\section{Реферат}

Використання у сенсорних структурах нанокристалів з великою питомою поверхнею передбачає їх високу чутливість до молекул адсорбованих газів. Метою роботи було створення сенсорних елементів на основі композитних плівок полі-3,4-етилендиоксітіофену (ПЕДОТ) у поєднанні 3 нанокристалами поруватого кремнію (ПК) та оксиду цинку ZnO i вивчення впливу адсорбції молекул аміаку, етанолу та ацетону на електричні параметри структури ПЕДОТ-ПК-ZnO.

Для виготовлення плівки гібридного композиту ПЕДОТ-ПК-ZnO використовували 1\% суспензію ПЕДОТ - ПСС та оксид цинку з розміром частинок до 100 нм (Sigma-Aldrich Co, США), а також нанокристали ПК, отримані електрохімічним травленням кремнієвої пластини. Дослідження адсорбційно-десорбційних процесів у композитних плівках здійснювалось вимірюванням їх електричних параметрів при різних концентраціях аналізованих газів. Для оцінки сенсорних властивостей розраховано адсорбційну чутливість композитних плівок і досліджено їх динамічні характеристики.

Зареєстровано збільшення електричного опору нанокомпозиту внаслідок адсорбції молекул аміаку, етанолу та ацетону. Спостерігались майже лінійні залежності опору від концентрації аміаку та ацетону, що є вагомою перевагою при розробці газових сенсорів. Максимальна чутливість сенсорних елементів знаходиться в діапазоні концентрацій аналізованих газів 1-2 \%, а час відклику становить 60-80 с. Плівки з більшим вмістом нанокристалів ПК володіли більшою чутливістю до молекул аміаку та етанолу, а плівки з більшим вмістом наночастинок $\mathrm{ZnO}$ - до молекул ацетону. Керувати функціональними параметрами плівкових сенсорів можна змінюючи співвідношення між вмістом напівпровідникових наночастинок у гібридному композиті.

Поєднання наночастинок поруватого кремнію та оксиду цинку забезпечує не лише збільшення площі робочої поверхні сенсорів, але й високу чутливість і селективність до молекул аміаку, етанолу та ацетону. Одержані результати можна використати для створення ефективних газоаналізаторів.

Ключові слова: сенсори, адсорбційна чутливість, нанокомпозит, поруватий кремній, оксид цинку, полі-3,4-етилендиоксітіофен 